\title{
Elektrikli Araç İçin Düşük Maliyetli Bir Batarya Yönetim Sistemi Tasarımı ve Gerçekleştirilmesi
}

\author{
Mustafa Aktaş ${ }^{1}$, Burak Baygüneş ${ }^{2}$, Sinan Kıvrak $^{3}$, Barış Çavuş ${ }^{4}$, Faruk Sözen ${ }^{5}$ \\ ${ }^{1}$ Ondokuz Mayıs Üniversitesi, Mühendislik Fakültesi, Elektrik Elektronik Mühendisliği Bölümü, Samsun, Türkiye (ORCID: 0000-0002-2608-1000) \\ ${ }^{2}$ Ondokuz Mayıs Üniversitesi, Mühendislik Fakültesi, Elektrik Elektronik Mühendisliği Bölümü, Samsun, Türkiye (ORCID: 0000-0003-2799-0801) \\ ${ }^{3}$ Yıldırım Beyazıt Üniversitesi, Mühendislik ve Doğa Bilimleri Fakültesi, Elektrik Elektronik Mühendisliği, Ankara, Türkiye (ORCID: 0000-0001-5195-0311) \\ ${ }^{4}$ Ondokuz Mayıs Üniversitesi, Mühendislik Fakültesi, Elektrik Elektronik Mühendisliği Bölümü, Samsun, Türkiye (ORCID: 0000-0002-5798-8350) \\ 5 Ondokuz Mayıs Üniversitesi, Mühendislik Fakültesi, Elektrik Elektronik Mühendisliği Bölümü, Samsun, Türkiye (ORCID: 0000-0003-1009-7187)
}

(Bu yayın 26-27 Haziran 2020 tarihinde HORA-2020 kongresinde sözlü olarak sunulmuştur.)

(DOI: 10.31590/ejosat.779720)

ATIF/REFERENCE: Aktaş, M., Baygüneş, B., Kıvrak, S., Çavuş, B. \& Sözen, F. (2020). Elektrikli Araç İçin Düşük Maliyetli Bir Batarya Yönetim Sistemi Tasarımı ve Gerçekleştirilmesi. Avrupa Bilim ve Teknoloji Dergisi, (Special Issue), 227-238.

$\ddot{O} z$

Fosil yakıt kaynaklarının yakında tükenecek olması ve bu yakıtlarla çalışan içten yanmalı motorlu araçların çevreye verdikleri zararlar nedeniyle Elektrikli Araç (EA)'ların önemi gün geçtikçe artmaktadır. EA'nın hareketinin sağlanabilmesi için kullanılan elektrik motorunun ihtiyaç duyduğu elektrik enerjisi genel olarak bataryalar tarafından sağlanmaktadır. EA'ların verimli ve güvenilir bir şekilde çalıştırılması bataryaların kullanımıyla doğrudan ilişkilidir. Bu durum, enerji kaynağı olarak kullanılan bataryaların durumlarını takip ve kontrol eden bir BYS'nin kullanılmasını zorunlu kılmaktadır. Bu çalışmada, elektrikli araçlarda kullanmak amacıyla 20 hücreli batarya paketi için pasif hücre dengeleme metodu temel alınarak Batarya Yönetim Sistemi (BYS) tasarlanmış ve üç hücreli BYS uygulaması gerçekleştirilmiştir. Li-ion bataryalar kullanılarak tasarımda 20 adet seri batarya hücresinin dengelenmesini pasif şekilde yapabilecek; aşırı gerilim, düşük gerilim ve sıcaklık koruması olan ve ayrıca bataryaların SoC'larını belirleyebilen, merkezi BYS yapısında bir kartın tasarımı gerçekleştirilmiş ve donanımsal devrenin gerçek çalışma durumu test edilmiştir. SoC hesaplamasında "terminal gerilimi”" yöntemi uygulanmıştır. Bu yöntem, batarya boşalırken iç empedanslar nedeniyle bataryada meydana gelen terminal gerilim düşümüne dayanmaktadır. BYS kartının tasarımında merkezi BYS sistemi tercih edilmiş ve SMD devre elemanları kullanılarak kartın sade olması sağlanmış, boyutu küçültülmüş ve maliyeti düşürülmüştür. Prototip olarak yapılan BYS kartında batarya hücreleri için aşırı gerilim, düşük gerilim ve sıcaklık korumaları mevcuttur. Ayrıca batarya hücrelerinde azami verim alınabilmesi amacıyla hücrelerin dolumu esnasında pasif dengeleme sistemi uygulanmaktadır. BYS ile batarya hücrelerinin her birinin SoC'ları hesaplanmış ve SoH kestirimleri yapılmıştır. Gerçekleştirilmiş olan BYS'nin belirtilen özellikleri test edilmiş ve sisteminin başarılı bir şekilde çalıştığı elde edilen deneysel sonuçlar aracılı̆̆ı ile ispatlanmıştır. Ayrıca, BYS tasarımında pasif dengeleme sistemi kullanılarak tasarım hızı, boyutu ile maliyet ve kurulum kolaylığı açısından iyileştirmeler sağlanmıştır.

Anahtar Kelimeler: Batarya Yönetim Sistemi, SoC, SoH, Li-ion.

\section{Design and Implementation of a Costly Battery Management System for Electric Vehicle}

\begin{abstract}
The importance of Electric Vehicle (EV) is increasing day by day due to the destruction of fossil fuels reserves and the damage caused by internal combustion engine vehicles working with fossil fuels to the environment. The necessary electrical energy of the electric motor used to ensure the movement of the EV is generally provided by the batteries. Efficient and reliable use of EV's is directly related to the use of batteries. For this reason, it requires the use of a BMS that monitors and controls the status of the batteries used as energy sources. In this study, the Battery Management System (BMS) was designed based on the passive cell balancing method for the 20 cell battery pack to be used in electric vehicles, and a three cell BMS application was implemented. Using Li-ion batteries, a PCB in the central BMS structure, which can passively balance the 20 serial battery cells in the design, and which can also determine the SoC of the batteries, has been designed and the actual working condition of the hardware circuit has been tested. In the SoC calculation, the "terminal voltage" method was applied. This method is based on terminal voltage level decrease occurring in the battery due to internal
\end{abstract}


impedances when the battery is discharged. In the design of the BMS pcb, the central BMS system was preferred and the pcb was made simple by using SMD components, the size was reduced and the cost was reduced.

In the BMS pcb made as prototype, there are overvoltage, undervoltage and temperature protections for battery cells. Also, in order to maximum efficiency in battery cells, passive balancing system is applied during the charging of the cells. SoC of each of the battery cells were calculated with BMS and SoH estimates were made. The specified properties of the realized BMS have been tested and proved by the experimental results obtained that the BMS has been operating successfully. In addition, improvements in design speed, size, cost and ease of installation have been achieved by using the passive balancing system in BMS design.

Keywords: Battery Management System, SoC, SoH, Li-ion.

\section{Giriş}

Fosil yakıtlarla çalışan içten yanmalı motorlu araçların yakıt rezervlerinin sınırlı olması ve bu araçların çevreye verdikleri zararlar nedeniyle Elektrikli Araç (EA)'lara olan ilgi gün geçtikçe artmaktadır [1,2]. EA'ların hareket edebilmek için ihtiyaç duyduğu mekanik itme gücü elektrik motorları tarafından sağlanmaktadır. Elektrik motorları, elektrik enerjisini mekanik enerjiye çevirirler ve gerekli olan elektrik enerjisini ise genel olarak bataryalardan temin ederler. Bundan dolayı EA'larda kullanılan bataryalar araç için çok büyük önem arz etmektedir. EA'ların verimli ve güvenilir bir şekilde kullanılması bataryaların kullanımıyla doğrudan ilişkilidir. Dolayısıyla, daha verimli ve güvenilir bir çalışma için, enerji kaynağı olarak kullanılan bataryaların durumlarını takip ve kontrol eden bir BYS'nin olması gerekmektedir [3]. BYS, EA uygulamalarında bataryaların etkin ve sağlıklı bir şekilde kullanımı için kilit rol üstlenmektedir. BYS, batarya gerilimi, sıcaklık ve Batarya Şarj (dolum) Durumu (SoC) gibi verileri sürekli denetler ve takip eder. Ayrıca, bataryalar ile ilgili verileri kullanıcıya aktarır ve bataryaların güvenli bir şekilde çalışmasını sağlamaktadır. BYS sıcaklık, gerilim ve akımların izlenmesini, bakımların planlamasını, bataryaların başarım optimizasyonunu, arıza tahminini ve/veya arıza önlemeyi ve ayrıca bataryadan veri toplanmasını/analizini içermektedir [4].

EA uygulamalarında batarya hücre ve paketlerini verimli ve güvenli bir şekilde kontrol etmek her zaman önemlidir. EA'larda çok fazla tercih edilen Lityum-İyon (Li-ion) pillerin çalışmalarının kontrolü için BYS'ye ihtiyaç vardır. Bunun nedenleri arasında, Li-ion pillerin aşırı dolumları, tamamen boşalmaları veya güvenli sıcaklık sınırlarının dışında çalıştırılmaları halinde arızalanmaları gösterilebilir [5,6]. Elektrikli araçlarda kullanılan her bir Li-ion bataryada, BYS'yi yaklaşık $0-100{ }^{\circ} \mathrm{C}$ aralığında çalışacak şekilde planlamayı gerekli kılan kendi güvenli çalışma alanına sahiptir.

BYS'de, bataryanın istenen çalışma aralığında çalışabilmesi için, batarya hücrelerine ait gerilim, akım ve sıcaklık değerlerinin sürekli izlenmesi gerekmektedir. Bu denetim ve izlemeler bir mikroişlemci kontrol ünitesi (MCU) tarafından gerçekleştirilmelidir. MCU, batarya hücrelerinden elde edilen verileri değerlendirerek, bataryanın korunmasını sağlamaktadır. Böylece, bataryalardan en yüksek seviyede verim alınmakta ve EA'nın kullanım özelliklerinin geliştirilmesine de yardımcı olmaktadır.

BYS temelde donanım açısından dört farklı şekilde tasarlanabilmektedir;

- Merkezi batarya yönetim sistemi

- Parçalı batarya yönetim sistemi

- Ana kart-yardımcı kart batarya yönetim sistemi

- Dağıtık batarya yönetim sistemi

Bu çalışmada Merkezi Batarya Yönetim Sistemi (MBYS) türü uygulanmıştır. MBYS basit yapıda olup sadece tek bir ana işlemciye sahip olduğu için maliyeti çok düşüktür ve kontrol işlemi basittir [7]. Tek bir işlemci bulunduğundan hücreler arasında ek olarak bir haberleşme birimine ihtiyaç duyulmaz. Her bir batarya hücresinin kontrol edilmesi için bu yöntemde kullanılacak işlemcinin çok sayıda dijital giriş-çıkışının olması gerekmektedir. Batarya sayısının fazla olması durumunda tek bir işlemcinin çıkış sayısı yetersiz olabilmektedir.

SoC, bataryalar için en önemli değişkenlerden biridir, ancak tanımı gereği birçok farklı durum ortaya koymaktadır [8]. SoC tahmin yöntemlerinin sınıflandırması literatürde farklılık göstermekle birlikte, bazı kaynaklar SoC hesaplama yöntemlerini aşağıdaki gibi dört bölüme ayırmaktadır [8,9];

1. Doğrudan ölçüm: Bu yöntem, bataryanın gerilimi ve empedansı gibi fiziksel batarya özelliklerini kullanmaktadır.

2. Defter tutma tahmini: Bu yöntem, giriş olarak boşalma akımını kullanmakta ve SoC'yi hesaplamak için boşalma akımını zaman içinde bütünleştirmektedir.

3. Uyarlamalı sistemler: Uyarlanabilir sistemler kendi kendine tasarımlıdır ve SoC'yi farklı boşalma koşulları için otomatik olarak ayarlayabilmektedir. SoC tahmini için çeşitli yeni uyarlamalı sistemler geliştirilmiştir.

4. Melez yöntemler: Bu modeller her SoC tahmin yönteminin iyi özelliklerinden yararlanmakta ve genel olarak azami bir tahmin başarımı sunmaktadır. Kaynaklarda melez yöntemlerin, tekil yöntemlere göre daha iyi bir SoC hesabı ürettiği belirtilmektedir.

Tablo 1'de metodoloji açısından belirli SoC hesaplama yöntemleri verilmektedir ve yöntemler BYS uygulamalarına göre farklılık göstermektedir. 
Tablo 1. SoC hesaplama matematiksel yöntemlerinin sinıflandırlmasl

\begin{tabular}{|c|c|}
\hline Kategori & Matematiksel Yöntem \\
\hline Doğrudan Ölçüm & $\begin{aligned} \text { i. } & \text { Açık Devre Gerilim Yöntemi } \\
\text { ii. } & \text { Terminal Gerilimi Yöntemi } \\
\text { iii. } & \text { Empedans Yöntemi } \\
\text { iv. } & \text { Empedans Spektroskopisi Yöntemi }\end{aligned}$ \\
\hline Defter Tutma Tahmini & $\begin{aligned} \text { i. } & \text { Coulomb Hesaplama Yöntemi } \\
\text { ii. } & \text { Güçlendirilmiş Coulomb Hesaplama Yöntemi }\end{aligned}$ \\
\hline Uyarlamalı Sistemler & 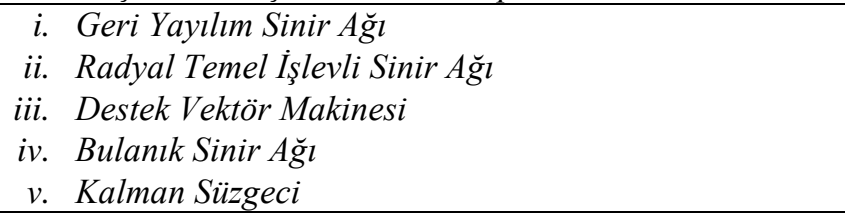 \\
\hline Melez Yöntemler & $\begin{aligned} \text { i. } & \text { Coulomb Hesaplama ve Elektromotor Kuvvet Birleşimi } \\
\text { ii. } & \text { Coulomb Hesaplama ve Kalman Süzgeç Birleşimi } \\
\text { iii. } & \text { Per-unit ve Genişletilmiş Kalman Süzgeç Birleşimi }\end{aligned}$ \\
\hline
\end{tabular}

Doğrudan ölçüm yöntemleri, terminal gerilimi ve empedansı gibi bazı fiziksel batarya özelliklerini kullanmaktadır. Açık devre gerilimi yönteminde, kurşun-asit bataryada $\mathrm{SoC}$ ve açık devre gerilimi (OCV) arasında yaklaşık olarak doğrusal bir ilişki olduğundan, SoC tahmini, OCV tahminine eşittir [10]. Bataryaların OCV'sini temel alan OCV yönteminde, bataryanın boşalmasından sonra yaklaşık iki saatten daha uzun bir süre beklemesiyle elde edilen terminal gerilimi $\mathrm{SoC}$ ile orantılıdır. Hatta bu süre, tahmin yöntemi için uygulanamayacak kadar uzun olabilmektedir [11]. SoC ile OCV ilişkisi, Li-ion batarya üzerine bir darbe yükü uygulanmasından sonra bataryanın dengeye ulaşmasına izin verilmesi ile tespit edilmektedir [12]. Terminal gerilimi yöntemi farklı deşarj akımlarında ve sıcaklıklarında kullanılmaktadır [13]. Ancak bataryanın deşarjının sonunda, terminal gerilimi yönteminin tahmin hatası büyüktür, çünkü bataryanın terminal gerilimi boşalma sonunda aniden düşmektedir [14]. Empedans ölçümleri yönteminde, empedans parametreleri ve SoC ile çeşitlemeleri, tüm batarya sistemleri için tek olmasa da, belirli bir bataryanın dolum durumunu tahmin etmek amacıyla empedans değişkenlerinin tanımlanmasında ve kullanılmasında çok çeşitli empedans deneyleri yapılması gerekmektedir $[9,15]$. Empedans spektroskopisi yönteminde, mevcut batarya empedanslarının ölçülmesi ve çeşitli SoC seviyelerinde bilinen empedanslarla ilişkilendirilmesi sayesinde SoC dolaylı olarak elde edilmektedir [16,17].

Defter tutma tahmin yöntemi, batarya boşalma akım verilerini girdi olarak kullanmaktadır. Bu yöntem, öz boşalma, kapasite kaybı ve boşalma verimliliği gibi bazı batarya etkilerini dahil etmeyi sağlamaktadır. Coulomb hesaplama yöntemi, bir bataryanın boşalma akımını ölçmekte ve SoC'yi tahmin etmek için, zamana göre boşalma akımını toplamaktadır [18]. Güçlendirilmiş Coulomb Hesaplama Yöntemi (GCHY), tahmin doğruluğunu artırmak için deşarj akımının bir fonksiyonu olan düzenlenmiş akımı kullanmaktadır.

Son zamanlarda, yapay zekanın gelişmesiyle birlikte, SoC tahmini için çeşitli uyarlanabilir sistemler geliştirilmiştir. Yeni geliştirilen yöntemlerin başlıcaları, Geri Yayılım Sinir Ağı, Radyal Temel İşlevli Sinir Ağı, Bulanık Mantık Yöntemleri, Destek Vektör Makinesi, Bulanık Sinir Ağı ve Kalman Filtresi olarak sayılabilir. Uyarlamalı sistemler, değişken sistemlerde otomatik olarak ayarlanabilen, kendi kendini tasarlayabilen sistemlerdir. Bataryalar birçok kimyasal faktörden etkilendiğinden ve bataryaların doğrusal olmayan SoC karakteristiği olduğundan, uyarlamalı sistemler SoC tahmini için etkili bir çözüm sunmaktadır [8].

Melez (hibrid) yöntemlerin hedefi ise, her yöntemin faydalarından yararlanmak ve genel olarak yüksek bir tahmin başarımı elde etmektir. Genellikle tekli yöntemlerle karşılaştırıldığında daha iyi SoC tahmin sonuçları üretmektedir [19-21]. Melez yöntemler, doğrudan ölçüm yöntemi ve defter tutma tahmin yöntemi gibi farklı yaklaşımları birleştirebilmektedir.

Bu çalışmada SoC hesaplamasında "Terminal Gerilimi Yöntemi” kullanılarak düşük maliyetli bir BYS tasarımı yapılmıştır. Tasarlanan sistemde bataryaların güvenli ve etkin şekilde çalışabilmesi için aşırı gerilim, aşırı deşarj ve yüksek sıcaklık korumaları mevcuttur. Bataryaların şarj esnasında korunması amacıyla pasif dengeleme metodu kullanılmıştır. Çalışma sonucunda BYS üzerinde yapılmış olan aşırı gerilim, aşırı deşarj, yüksek sıcaklık koruma ve pasif dengeleme test sonuçlarına yer verilmiştir.

\section{Materyal ve Metot}

\subsection{Giriş}

Bu çalışmada Li-ion bataryalar için kullanılabilecek bir BYS tasarımı yapılmıştır. Bu amaçla 20 adet seri batarya hücresinin dengelenmesini pasif şekilde yapabilecek; aşırı gerilim, düşük gerilim ve sıcaklık koruması olan ve ayrıca bataryaların SoC'larını belirleyebilen, merkezi BYS yapısında bir kartın tasarımı gerçekleştirilmiştir ve donanımsal sistemin deneysel çalışması farklı durumlar için gerçekleştirilmiştir. vardır.

BYS'ye bağlanacak batarya hücrelerinin dengelenme işlemlerinin yapılabilmesi için hücrelerin gerilim değerleri bilgisine ihtiyaç 


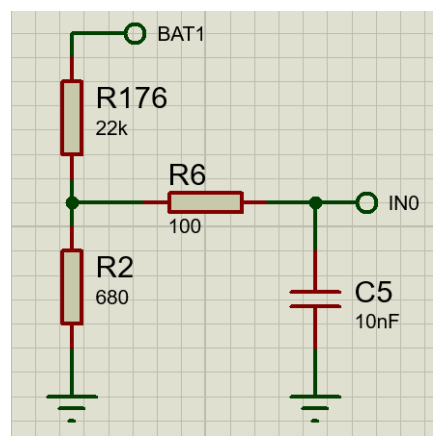

\section{Şekil 1 Gerilim bölücü ve alçak geçiren filtre devresi}

BYS'de kullanılan STM32F103C8T6 mikroişlemcinin 12 bitlik analog-sayısal dönüştürücü (ADC) girişleri 0-3.3 V arasındadır. Devrede batarya hücrelerine seri olarak bağlı iki direncin arasından gerilim değerleri bölünerek elde edilmektedir. n-adet VM üst çalışma sınırı olan bataryaların kullanılacağı sistemde batarya gerilimi, Şekil 1'de belirtilen gerilim bölücü devresi ile MCU'ya iletilmekte ve bu değer MCU tarafindan sayısala dönüştürülmektedir. MCU içinde analog değer AV(n) aşağıdaki gibi hesaplanmaktadır

$$
A V(I)=\frac{n \times V_{M}}{R_{176}+R_{2}} \times R_{2} \quad \ldots \quad A V(n)=\frac{1 \times V_{M}}{R_{176}+R_{2}} \times R_{2}
$$

Mikroişlemcinin ADC girişinden alınan bu gerilim;

$$
\operatorname{bat}(1)=\frac{A V(1) \times 4096}{3.3} \quad \ldots \quad \operatorname{bat}(n)=\frac{A V(n) \times 4096}{3.3}
$$

eşitlikleri kullanılarak MCU tarafından bat(n) sayısal değerine dönüştürülmektedir. Bu çalışmada tasarlanan BYS'de 1'den 16'ya kadar olan batarya hücrelerinde gerilim bölücü olarak 22k-680 $\Omega$ seri dirençleri kullanılmıştır. Geriye kalan batarya hücrelerinden 17-18 numaralı hücrelerde $22 \mathrm{k}-4.7 \mathrm{k} \Omega, 19$. bataryada $22 \mathrm{k}-10 \mathrm{k} \Omega$ ve son bataryada $22 \mathrm{k}-22 \mathrm{k} \Omega$ dirençler gerilim bölücü olarak kullanılmıştır. $\mathrm{Bu}$ direnç değerlerindeki farklılığın sebebi analog değerin daha doğru olarak elde edilebilmesidir.

Elde edilen bat(n) sayısal değerleri işlemcide tekrar okunan analog gerilime dönüştürülmektedir ve analog değerler gerilim bölücü devresindeki direnç değerleri kullanılarak Vbat (Bat(n) gerilimi) olarak batarya hücrelerinin artı ucu ile nötr arası gerilime aşağıdaki gibi dönüştürülmektedir.

$$
V_{\text {batl }}=\left(\frac{\text { bat }(1) \times 3.3}{4096}\right) \times\left(\frac{R_{176}+R_{2}}{R_{2}}\right) \ldots \quad V_{\text {batn }}=\left(\frac{\text { bat }(n) \times 3.3}{4096}\right) \times\left(\frac{R_{176}+R_{2}}{R_{2}}\right)
$$

Bu şekilde ölçümü yapılan batarya gerilimlerinde; 1. batarya hücresinden yapılan gerilim değeri ölçümü aslında tüm batarya hücrelerinin gerilimlerinin toplamının ölçümüdür. 2. batarya hücresinden yapılan gerilim ölçümü ise kalan 19 bataryanın gerilimidir. 3 . hücreden alınan gerilim değeri de aynı şekilde 18 bataryanın gerilim ölçümünü göstermektedir. Bu şekilde devam ederek tüm gerilim ölçümleri yapılmaktadır.

BYS'lerde batarya hücrelerinin sıcaklığı, bilinmesi gereken en önemli verilerden biridir. Batarya grubunu oluşturan her bir batarya paketinin sıcaklığı LM35 entegresi kullanılarak ölçülmektedir. Her bir batarya paketi içerisine birer adet ve ayrıca ortam sıcaklık ölçümü için bir adet olmak üzere 5 adet LM35 entegresi devreye Şekil 2'deki gibi bağlanmaktadır ve ölçümler analog olarak alınmaktadır.

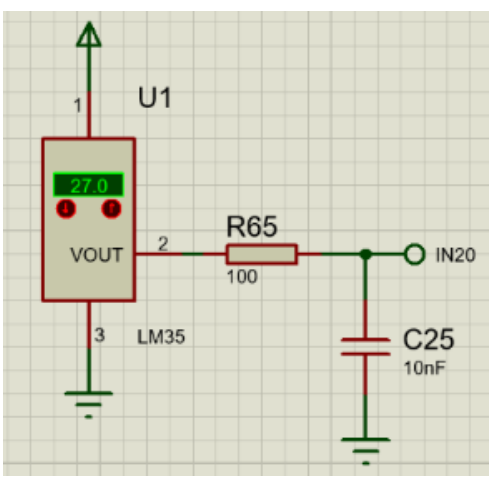

Şekil 2. LM35 ve alçak geçiren filtre devresi

Genel olarak k-adet LM35 sıcaklık algılayıcısı çıkışlarından alınan analog gerilimler (analogdeğer(k)), MCU'nun ADC'si tarafından aşağıda verilen denklemdeki gibi sicaklik(k) sayısal değerlerine dönüştürülmektedir.

analogde ğer $(k)=\operatorname{SicaklıkDeğeri~}(k)\left({ }^{\circ} C\right) \times 0.01$ 
$\operatorname{sicaklik}(k)=\frac{\text { analogdeğer }(k) \times 4096}{3.3}$

MCU'da sicaklik(k) sayısal değerleri de,

$$
\operatorname{Grup}(k)=\frac{\operatorname{sicaklik}(k) \times 3.3}{4096}
$$

eşitlikleri kullanılarak Grup(k) analog gerilim değerine dönüştürülmektedir. LM35 algılayıcısı için her $10 \mathrm{mV}$ değeri $1^{\circ} \mathrm{C}$ olduğundan, algılayıcıdaki gerçek sıcaklığın ${ }^{\circ} \mathrm{C}$ değeri;

$$
\operatorname{Temp}(k)=\frac{\operatorname{Grup}(k)}{0.01}
$$

olarak elde edilmektedir. Çalışmada kullanılan 5 adet algılayıcı için de bu değerler ayrı ayrı hesaplanmaktadır.

Ölçülen batarya sıcaklık değerlerine bağlı olarak, sistemi korumak adına sıcaklık seviyeleri belli değere geldiğinde sistemi soğutmak için fan devreye alınmaktadır. Eğer devrede herhangi bir algılayıcıdan alınan sıcaklık değeri $40^{\circ} \mathrm{C}$ üstüne çıkarsa, batarya hücrelerini soğutmak için öncelikle, devreye bağlı fan çalışacaktır. Devreye alınan fan vasıtasıyla sıcaklığın aşırı yükselmesi engellenmek istenmektedir. Fana rağmen sıcaklık yükselmeye devam eder ve $60^{\circ} \mathrm{C}$ 'ye ulaşırsa, BYS acil röle açma sinyali vererek batarya dolumunu/boşalmasını durduracak ve hücre dengelemesine de son verilecektir.

$\mathrm{Bu}$ çalışmada tasarlanan donanım 20 adet batarya hücresi için gerçekleştirildiğinden, çok sayıda veri alınması gerekmektedir. Bataryalardan alınan veriler Şekil 3'te iki adet analog MUX (CD4067) kullanılarak belirlenen sıralarla MCU'ya aktarılmaktadır.

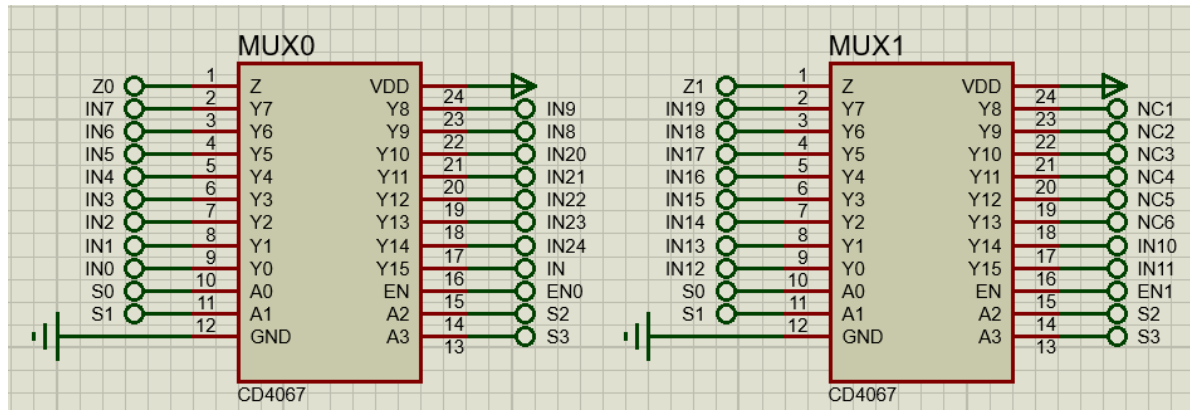

Şekil 3. Veri seçme devresi

MUX'lara gelen analog veriler sırayla MCU'ya gönderilecektir. Kullanılan MUX'ları aktif etmek için bir giriş ve verileri seçmek için de 4 adet seçme giriş (S0, S1, S2, S3) bulunmaktadır. Devreden toplanan analog ölçüm verileri, işlemciden gönderilen sayısal çıkışlarla, MUX'ların sırayla çıkış vermesi sonucu mikroişlemciye iletilmektedir.

\subsection{Batarya Pasif Dengeleme}

Batarya hücrelerinden toplanan ölçüm verileri değerlendirilerek gerilimi fazla olan batarya hücreleri dengelenmektedir. Bu çalışmada pasif batarya dengelemesi sadece bataryaların dolum işlemi sırasında yapılmaktadır. ACS712 30A'lık akım algılayıcısı kullanılarak çalışma sırasında devrenin dolum ya da boşalma durumunda olduğu ve bataryalardan geçen akımın yönü tespit edilmektedir. Akımda meydana gelen her 1 A'lık değişimde algılayıcı çıkış gerilimi 66 mV değişmektedir. Algılayıcı çıkışı mikroişlemci girişine verildikten sonra akım analogdeğeri ADC ile akim sayısal değerine dönüştürülmektedir. Bu değer ise MCU'daki yazılım ile tekrar akim1 analog gerilim değerine çevrilmektedir. Böylece gerçek değer yani algılayıcının çıkış gerilimi tekrar elde edilmektedir. Algılayıcı çıkış gerilimi kullanılarak akımın değeri olan GercekAkim aşağıdaki gibi hesaplanmaktadır.

$$
\begin{aligned}
& \text { analogdeğer }=2.5 \pm(\text { akımde } \breve{g} \text { eri }) \times 0.066 \\
& \text { akim }=\frac{\text { analogde } \breve{g e r} \times 4096}{3.3} \\
& \operatorname{akim} 1=\frac{\operatorname{akim} \times 3.3}{4096} \\
& \text { GercekAkim }=\frac{(\text { akiml }-2.5)}{0.066}
\end{aligned}
$$

Akım değerinin negatif (-) olması batarya hücrelerinin boşaldığını, pozitif (+) olması ise hücrelerin dolmakta olduğunu göstermektedir. Bataryalar boşalma durumunda ise, BYS'nin batarya hücrelerini dengeleme yapması engellenmekte ve bataryaların enerjisinin boşa harcanmasının önüne geçilmektedir. Eğer devre dolum durumunda ise BYS dengeleme işlemi yapabilir demektir. Tasarlanan BYS kartında yapılacak olan pasif hücre dengelemesi Şekil 4'teki devre kullanılarak yapılmaktadır. 


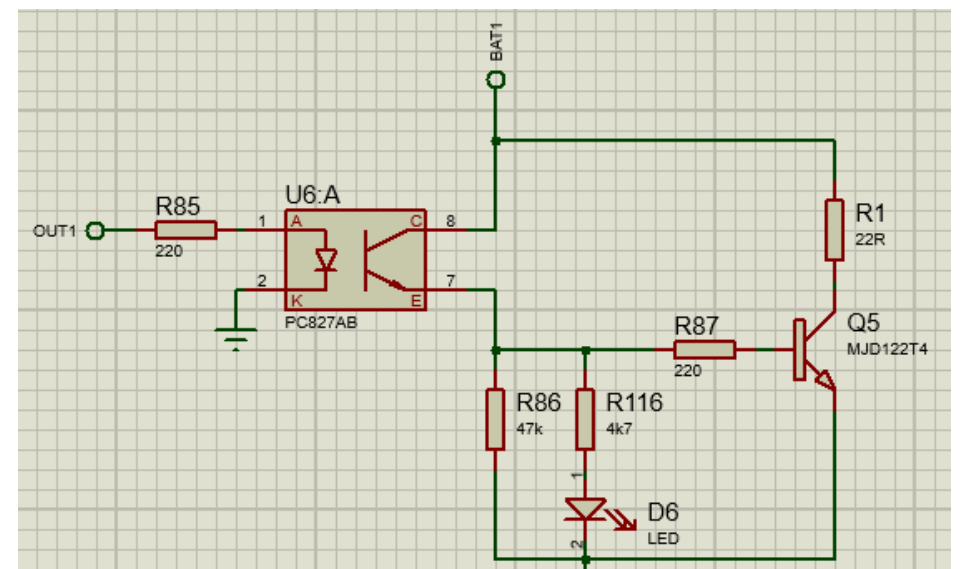

Şekil 4. Batarya dengeleme devresi

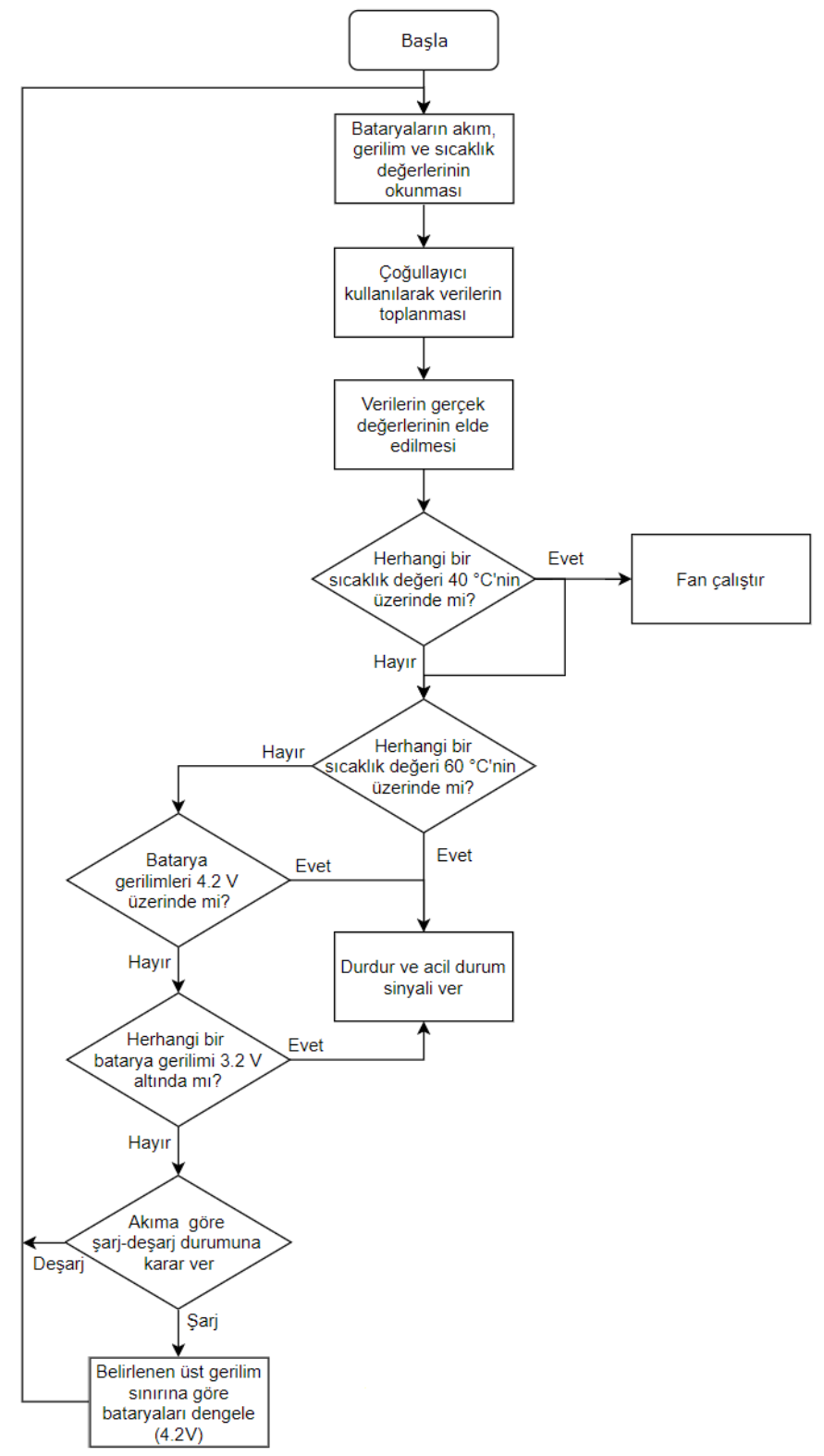

Şekil 5(a). BYS üst sinır (4.2V) dengeleme yöntemi

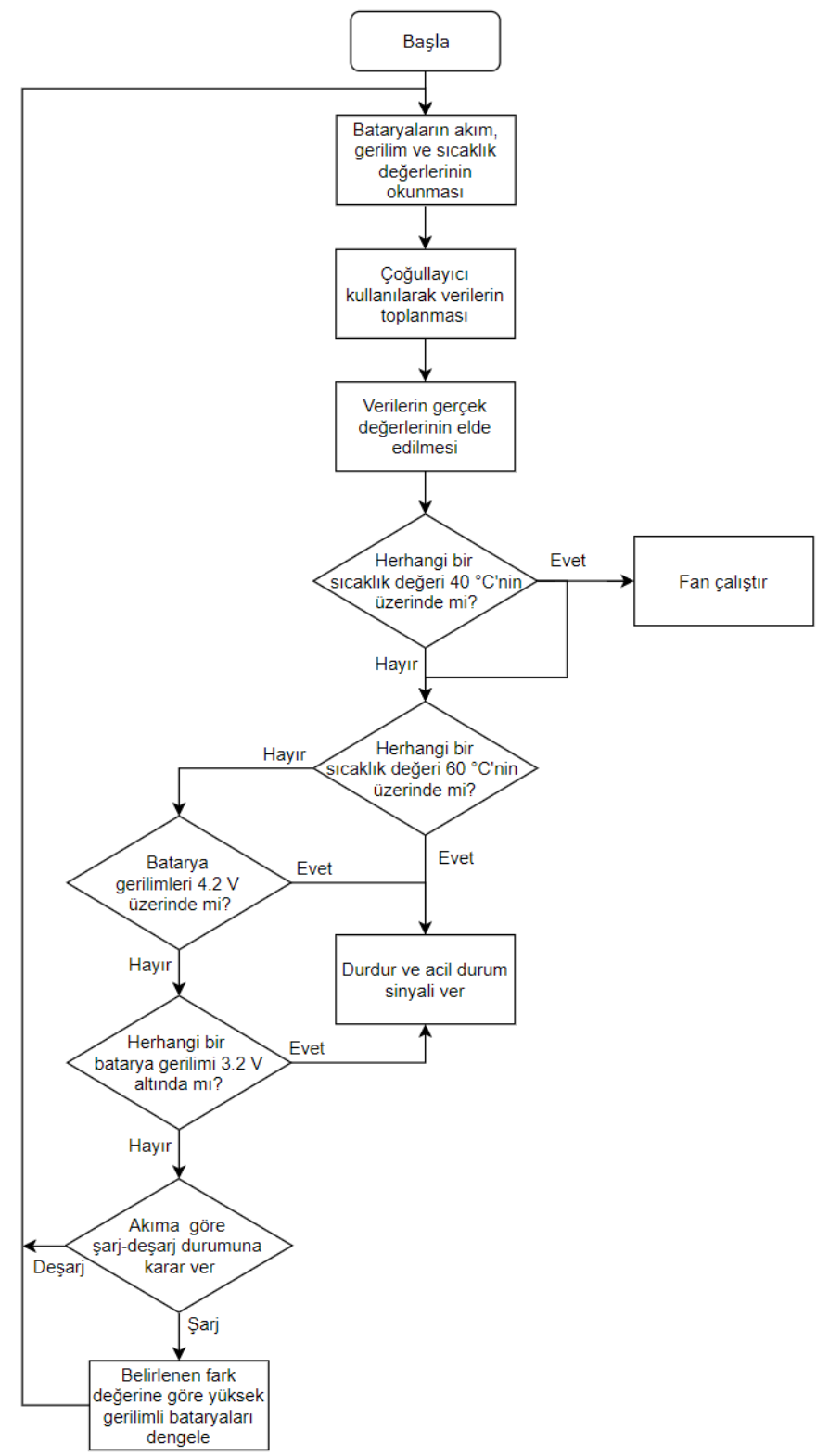

Şekil 5(b). BYS fark dengeleme yöntemi akuşşsemaları

Tasarımda kullanılacak olan pasif dengeleme iki türlü olarak yapılmaktadır. Birincisi, akış diyagramı Şekil 5(a)'da gösterilen, bataryaların üst sınır değerine gelmesiyle dengeleme işlemine girmektedirler. Bu sayede üst sınıra ulaşan batarya hücrelerine gelen akım, Şekil 4'te görüldüğü gibi, o hücrelere paralel bağlı olan direnç üzerinden geçirilerek enerji olarak harcanmakta, diğerleri dolmaya 
devam etmektedir. Kontrol algoritması basit olan bu yöntemde, batarya gerilimlerinin belirlenmesi dengeleme işlemi için yeterli olmaktadir.

İkincisi, akış şeması Şekil 5(b)'de verilen fark dengeleme algoritmasıdır. MCU'da hesaplanan batarya hücrelerinin gerilimlerinin karşılaştırılması sonucu en düşük gerilime sahip batarya belirlenir. Bu işlemin ardından, en düşük gerilimli batarya gerilimi ile diğer batarya gerilimlerinin tek tek farkı hesaplanmakta böylece her bir bataryanın gerilim fazlalığı tespit edilmektedir. Batarya hücreleri arasındaki gerilim farkı belirlenen değeri aştığında o batarya hücresindeki enerji, ilk yöntemin benzeri gibi yüksek güçlü dirençler üzerinden harcanarak gerilim farkı azaltılmakta ve belli bir gerilim farkı değerinde kalması sağlanmaktadır.

Her iki yöntemde de MCU'dan gelen sinyallere göre dengeleme devresindeki optoküplör arac1lığıyla MJD122T4 transistörler iletime geçirilmektedir. Bu sayede dengeleme işlemine alınan batarya hücrelerindeki enerji $22 \mathrm{Ohm}(5 \mathrm{~W})$ 'luk dirençler üzerinde harcanarak pasif olarak dengeleme yöntemi uygulanmaktadır. Her iki yöntemde de amaç, batarya hücrelerinin dolum esnasında hücrelerin aşırı dolumuna engel olarak hücreleri korumaktır. Dengeleme devresinde yer alan PC827 optokuplörler, kartın güç kısmı ile MCU kısmını birbirinden elektriksel olarak yalıtmaktadır. Böylece herhangi bir olumsuz durumda akım artışından zayıf akımlı devrenin etkilenmesini önlenmektedir. Devredeki kırmızı ledler sayesinde hangi bataryalar üzerinde dengeleme işlemi yapıldığı görsel olarak takip edilebilebilmektedir.

\subsection{SoC Hesaplama}

Genel olarak, bataryalar için en önemli değişkenlerden biri olan SoC, $Q(t)$ mevcut şarj miktarının, $C(n)$ anma kapasitesine oranı olarak tanımlanmaktadır. Anma kapasite, üretici tarafından verilmekte ve bataryada saklanabilecek azami enerji miktarını temsil etmektedir. SoC(t) aşağıdaki gibi tanımlanabilmektedir.

$$
\operatorname{SoC}(t)=\frac{Q(t)}{C(n)}
$$

Bu çalışmada SoC hesaplanması için Terminal gerilimi yöntemi uygulanmıştır. Bu yöntemde, batarya boşalırken, iç empedanslar nedeniyle bataryada meydana gelen terminal gerilimi düşümlerine dayanmaktadır. Bu nedenle, bataryanın Elektromotor Kuvveti (EMF) terminal gerilimi ile orantılıdır. Bataryanın EMF'si SoC ile yaklaşık olarak orantılı olduğundan, bataryanın terminal gerilimi de SoC ile yaklaşık olarak orantılıdır.

$\mathrm{Bu}$ çalışmada tasarlanan ve gerçekleştirilen BYS kartında SoC hesaplanması yapılmaktadır. SoC hesaplamasında ise daha önce bahsedilen terminal gerilimi yöntemi kullanılmışırı. Batarya üreticisinin verdiği batarya gerilimi-boşalım ilişkisini gösteren grafik/veriler kullanılarak, MATLAB m-file ile Şekil 6'daki eğri elde edilmiştir.

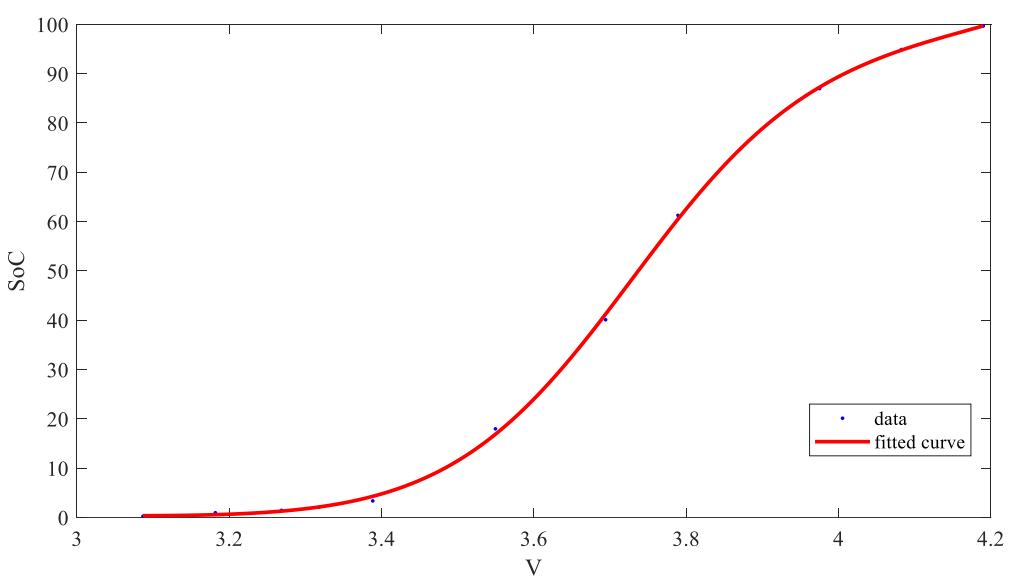

Şekil 6. VT-Boşalım karakteristiğine uydurulan e ğri

VT batarya terminal gerilimi olmak üzere, eğri uydurma yöntemi ile \%SoC için elde edilen denklem aşağıdaki gibidir.

$$
f\left(V_{T}\right)=\frac{9.9622 \times V_{T}^{5}-49.6198 \times V_{T}^{4}+31.0136 \times V_{T}^{3}-53.4720 \times V_{T}^{2}+103.1386 \times V_{T}-18.3271}{V_{T}^{4}-7.2543 \times V_{T}^{3}+15.4334 \times V_{T}^{2}-11.8796 \times V_{T}+16.3099}
$$

BYS'nin çalışması esnasında her bir kod döngüsünde sistemdeki tüm batarya hücrelerinin gerilimi ölçülmektedir. Ölçülen bu batarya hücresi gerilimlerine bağlı olarak, elde edilmiş olan $\mathrm{f}(\mathrm{VT})$ fonksiyonu kullanılarak SoC hesabı yapılmaktadır.

\subsection{SoH Hesaplama}

Yapılan çalışmada Batarya Sağlık Durumu (SoH) kestirimi için bataryaların iç dirençlerinin değerleri kullanılmaktadır. BYS, çalışmasının ilk durumunda bataryanın boşalma işlemine başlamadan önce bataryaların açık devre (OCV-Open Circuit Voltage) gerilimleri ölçülür. Boşalma işlemi başladıktan sonra her bir batarya hücresinin gerilimi tekrar ölçülür. Batarya hücresinin ölçülen iki gerilimi arasındaki farkın akım sensöründen alınan değere bölünmesiyle batarya hücresinin iç direnci elde edilmektedir. 


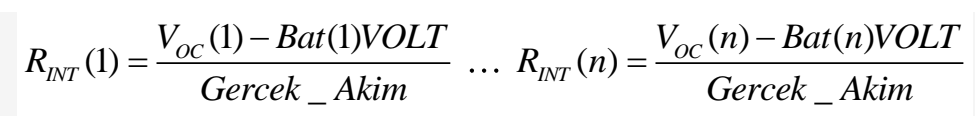

SoH kestirimi için yeni bir batarya hücresi ile $(\% \mathrm{SoH}=100)$, ömrünü tamamlamış bir batarya hücresinin $(\% \mathrm{SoH}=0)$ iç dirençleri temel alınarak Şekil 7'deki gibi doğrusal işlev olduğu kabul edilebilir.

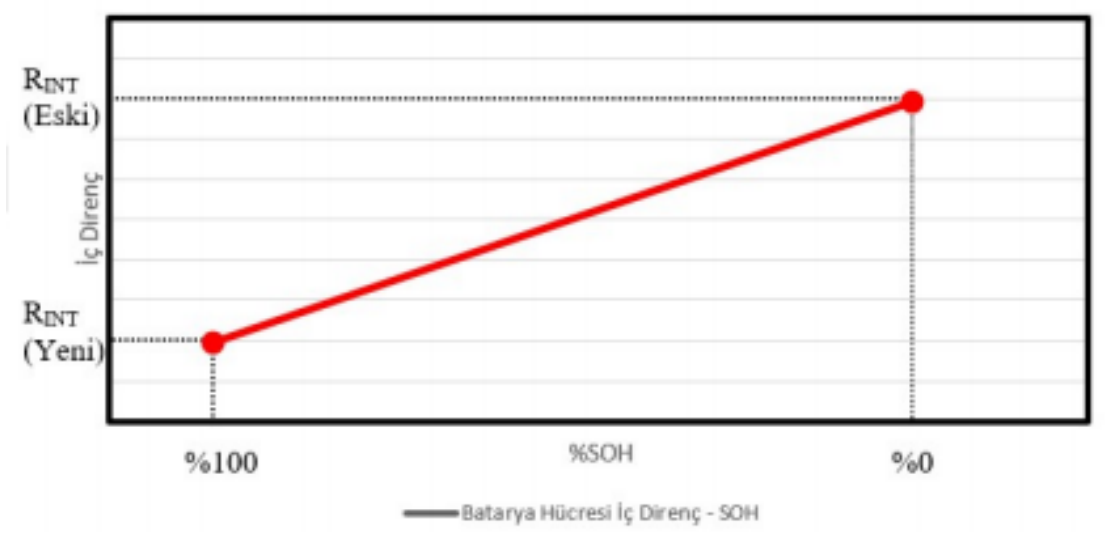

Şekil 7. Batarya hücresi iç direnci - SoH ilişkisi

Batarya iç direnci batarya eskidikçe artar. İç direnci artan bataryadan akım akmaya başladığında daha çok 1sınır. Batarya direnci ile SoH arasındaki ilişski doğrusal kabul edilmektedir;

$$
\% \operatorname{SoH}(1)=\frac{100 \times\left(R_{I N T}(e s k i)-R_{I N T}(1)\right)}{R_{I N T}(e s k i)-R_{I N T}(y e n i)} \ldots \% \operatorname{SoH}(n)=\frac{100 \times\left(R_{I N T}(e s k i)-R_{I N T}(n)\right)}{R_{I N T}(e s k i)-R_{I N T}(y e n i)}
$$

Bu eşitliklerde yer aldığı üzere yeni bir bataryanın ve kullanılamaz olduğu düşünülen bir bataryanın iç dirençleri referans alınarak batarya hücrelerinin SoH'u belirlenmektedir.

\section{Bulgular}

$\mathrm{Bu}$ çalışmada EA'da enerji kaynağı olan Li-ion bataryaların kontrol ve korumasında kullanılan pasif dengelemeli "Batarya Yönetim Sistemi” tasarımı ve uygulaması gerçekleştirilmiştir. Tasarlanan BYS kartı Şekil 8'de verilmiştir. Tasarlanan BYS'nin çalışması 5 adet Li-ion batarya hücresi bağlanarak test edilmiştir. Batarya hücrelerinin dengelenmesi aşamasında hücrelerin gerilimleri ölçülmüş ve dengelemeye girme durumları kontrol edilmiştir.

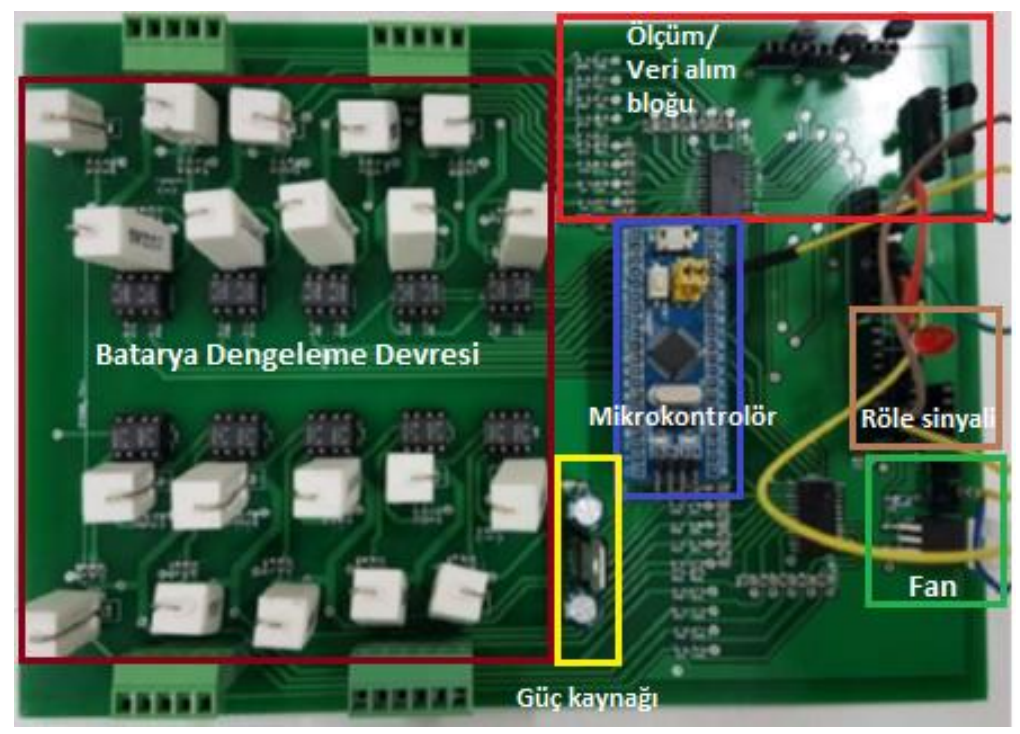

Şekil 8. Tasarlanan ve testi gerçekleştirilen 20 hücreli BYS kartı

Tablo 2'de görüldüğü gibi 5. hücre gerilimi en düşük batarya hücresidir. Dolayısıyla dengeleme işlemi 5. hücrenin gerilim değerine göre yapılmaktadır. Dengeleme değeri olarak da gerilim farkı $0.1 \mathrm{~V}$ olarak belirlendiğinde, 3 . ve 4 . hücreler bu değerin üstünde oldukları için dengelemeye girmekte ve ledleri yanmaktadır (lojik-1). 5. hücrenin kendisi ve 2. hücre ise değerin altında oldukları için dengelemeye girmemekte ve ledleri sönük (lojik-0) durumdadır. 1. hücre ise tam sınır değerde yer aldığı için ledi sürekli yanıp sönmekte, yani dengelemeye girip çıkmaktadır. 
Dengeleme gerilim farkı $0.3 \mathrm{~V}$ olarak belirlendiğinde ise 3. ve 4. hücreler sınır değerine yakın olduklarından ledleri sürekli yanıp sönmekte, yani dengelemeye girip çıkmaktadırlar.

Tablo 2. Hücre dengelemede değiş̧ik fark değerleri için sonuçlar

\begin{tabular}{c|c|c|c}
\hline Hücre & Gerilim & $\begin{array}{c}\text { Led Durumu } \\
\text { (Fark Değeri 0,1 V) }\end{array}$ & $\begin{array}{c}\text { Led Durumu } \\
\text { (Fark Değeri 0,3 V) }\end{array}$ \\
\hline 1. hücre & 3,45 & $1-0$ & 0 \\
\hline 2. hücre & 3,40 & 0 & 0 \\
\hline 3. hücre & 3,64 & 1 & $1-0$ \\
\hline 4. hücre & 3,68 & 1 & $1-0$ \\
\hline 5. hücre & 3,36 & 0 & 0 \\
\hline
\end{tabular}

Hücrelerin alternatif yöntem olarak üst sınır değere göre dengeleme durumları test edilmiştir. Üst sınır değer olarak $4.2 \mathrm{~V}$ ve test amaçlı batarya gerilimleri göz önüne alınarak 3.6 V seçilmiştir. Tablo 3'te görüldüğü üzere tüm batarya hücre gerilim değerleri 4.2 V'den düşük olduğu için hiçbir hücre dengelemeye girmemekte ve ledler sönük (lojik-0) durumdadır. $3.6 \mathrm{~V}$ değeri test edildiğinde ise 3. ve 4. hücre bu değerin üstünde olduğu için hücreler paralel dirençler üzerinden dengelemeye girmekte ve ledleri yanmaktadır (lojik1). Diğer hücre gerilimleri ise belirlenen değerin altında oldukları için dengeleme durumu dışındadırlar ve ledleri yanmamaktadır.

Tablo 3. Hücre dengeleme üst değer dengeleme sonuçları

\begin{tabular}{c|c|c|c}
\hline \multicolumn{4}{c}{ Hücre Üst Değer Dengeleme Değeri 4.2 V - 3.6 V } \\
\hline \multirow{2}{*}{ Batarya } & \multirow{2}{*}{ Gerilimi } & Led Durumu (Dengeleme) \\
\cline { 3 - 4 } & & $4.2 \mathrm{~V}$ & $3.6 \mathrm{~V}$ \\
\hline 1. hücre & 3.45 & 0 & 0 \\
\hline 2. hücre & 3.40 & 0 & 0 \\
\hline 3. hücre & 3.64 & 0 & 1 \\
\hline 4. hücre & 3.68 & 0 & 1 \\
\hline 5. hücre & 3.36 & 0 & 0 \\
\hline
\end{tabular}

Tasarlanan BYS'nin aşırı-düşük gerilim sınır koruması da test edilmiştir. Hücrelerden elde edilen verilere göre belirlenmiş sınır değerlerine göre röle koruma sinyali gözlemlenmiştir. Bataryanın dolum durumunda, batarya hücrelerinin azami çalışma gerilim seviyesi olan $4.2 \mathrm{~V}$ 'da ve ek olarak sistemi test etmek amaçlı batarya hücresi gerilim seviyesine göre belirlenmiş $3.3 \mathrm{~V}$ 'da aşırı dolum testi yapılmıştır. Ayrı ayrı değerler ( $4.2 \mathrm{~V}$ ve $3.3 \mathrm{~V}$ ) referans alınarak Tablo 4 'te görüldüğü gibi sistemin üst sınır röle koruma sinyali kontrol edilmiş ve sistemin düzgün çalıştı̆ı görülmüşsür. Sistem şarj durumunda tüm batarya hücreleri üst sınıra ulaşınca aşırı gerilim koruma sinyali gönderilerek hücrelerin dolumunun sonlandırılmasının yanında, batarya hücrelerinin dengelemesini de durdurmaktadır.

Tablo 4. Hücre aşırı gerilim koruma test sonuçları

\begin{tabular}{c|c|c|c}
\hline \multicolumn{3}{c}{ Hücre Aşırı Gerilim Koruma Test } \\
\hline \multirow{2}{*}{ Batarya } & \multirow{2}{*}{ Gerilim } & Led Durumu (Koruma Sinyali) \\
\cline { 2 - 2 } & & $4.2 \mathrm{~V}$ & $3.3 \mathrm{~V}$ \\
\hline 1. hücre & 3.453 & & \\
\hline 2. hücre & 3.425 & & \multirow{2}{*}{1} \\
\hline 3. hücre & 3.546 & \multirow{2}{*}{0} & \multirow{2}{*}{0} \\
\hline 4. hücre & 3.580 & & \\
\hline 5. hücre & 3.366 & & \\
\hline
\end{tabular}

Tablo 5'da bataryaların boşalma durumunda, ayrı ayrı değerler $(3.7 \mathrm{~V}$ ve $3.3 \mathrm{~V})$ referans alınarak sistemin alt sınır koruma sinyali kontrol edilmiş ve sistemin düzgün çalıştığ görülmüştür. Herhangi bir hücre anma değerlerine göre seçilmiş olan alt sinıra $(3.3 \mathrm{~V})$ ulaştığı anda BYS aşırı boşalma koruma röle sinyali vermekte ve hücre dengelemesini durdurmaktadır.

Tablo 5. Hücre düşük gerilim koruma test sonuçları 


\begin{tabular}{c|c|c|c}
\hline \multicolumn{4}{|c}{ Hücre Düşük Gerilim Koruma Test } \\
\hline \multirow{2}{*}{ Batarya } & \multirow{2}{*}{ Gerilim } & Led Durumu (Koruma Sinyali) \\
\cline { 2 - 2 } & & $3.7 \mathrm{~V}$ & 3.3 V \\
\hline 1. hücre & 3.453 & & \\
\hline 2. hücre & 3.425 & & \multirow{2}{*}{0} \\
\hline 3. hücre & 3.546 & 1 & 0 \\
\hline 4. hücre & 3.580 & & \\
\hline 5. hücre & 3.366 & & \\
\hline
\end{tabular}

BYS'nin farklı sıcaklıklarda çalışma durumları üzerinde de testler yapılmıştır. LM35 sıcaklık algılayıcısı 1sıtılarak sıcaklık korumalarının devreye girmesi incelenmiştir. Mikroişlemci yazılımı ile sıcaklık $40^{\circ} \mathrm{C}$ olduğunda soğutma amaçlı olarak fanın çalışması, fanın yetersiz kalıp ısınmanın devam etmesi ve sıcaklı̆̆ın $60^{\circ} \mathrm{C}$ üzerine çıkması durumunda, koruma sinyali gönderilip dengeleme işleminin durdurulması beklenmektedir. Algılayıcıyı 1sıtma işlemi sonucunda, Tablo 6'da verilen değerlerde görüldüğü gibi, yaklaşık $31^{\circ} \mathrm{C}$ 'de fan çalışmamakta ve röle koruma sinyali gönderilmemektedir. Yaklaşık olarak $42^{\circ} \mathrm{C}$ ' de fan çalışmakta ve röle koruma sinyali gönderilmemektedir. Son olarak $62^{\circ} \mathrm{C}$ 'de ise fan çalışırken, sistem koruma sinyali gönderilmekte ve batarya hücre dengelemesi durdurulmaktadır. Bu testler ile BYS'nin sıcaklık korumasını başarılı bir şekilde gerçekleştirdiği gözlemlenmiştir.

Tablo 6. Sicaklik koruma test sonuçları

\begin{tabular}{c|c|c}
\hline \multicolumn{3}{c}{ Sıcaklık Korumalar Test $\left(\right.$ Fan $40^{\circ} \mathrm{C}-$ Koruma Sinyali $\left.60^{\circ} \mathrm{C}\right)$} \\
\hline Algılayıcı Çıkışı & Fan & Led Durumu (Koruma Sinyali) \\
\hline $310 \mathrm{mV}$ & Pasif & 0 \\
\hline $420 \mathrm{mV}$ & Aktif & 0 \\
\hline $610 \mathrm{mV}$ & Aktif & 1 \\
\hline
\end{tabular}

Batarya hücrelerinin $0.2 \mathrm{~A}$ ile dolumu yapılırken, gerçekleştirilmiş olan BYS kartı üzerinden hücrelerin gerilim değerleri MATLAB kullanılarak gerçek zamanlı olarak kaydedilmiştir. Bu şekilde batarya hücrelerinin gerilimlerinin değişimi grafiksel olarak gözlemlenmiştir.

Şekil 9'da ilk hücre "BYS üst sınır dengeleme yöntemi" ile "bataryaların üst sınır değeri”ne gelmesiyle yapılacak dengelemenin batarya hücre gerilim değerlerinin değişimleri yer almaktadır.

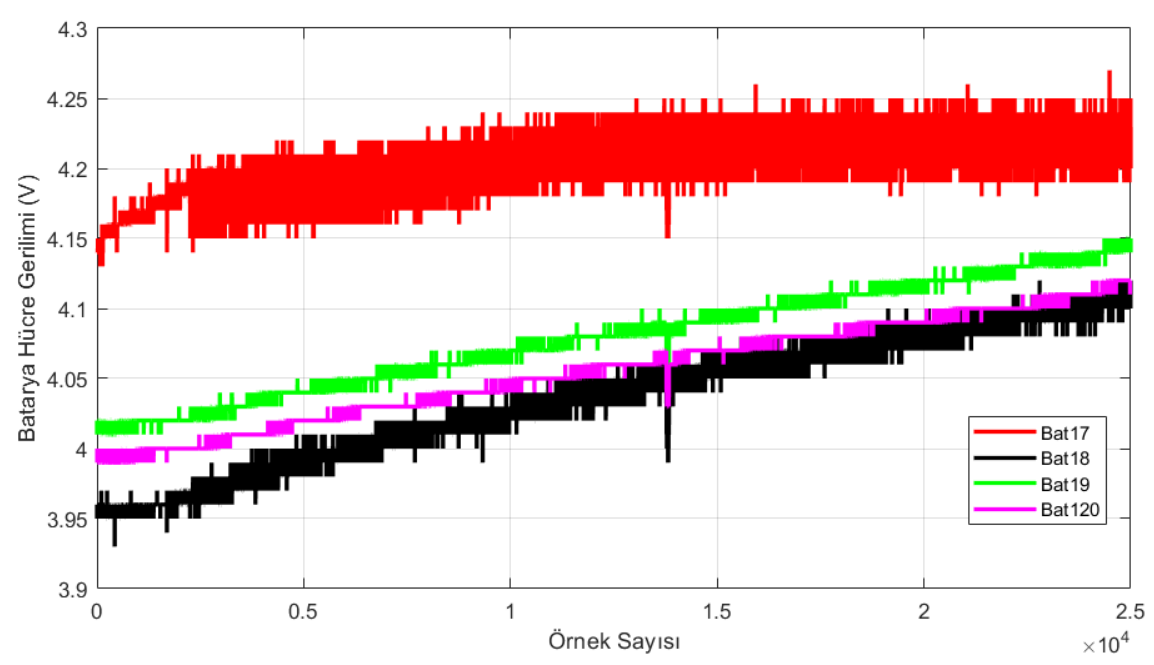

Şekil 9. Üst sinır değer dengeleme hücre gerilimleri

Şekil 9'da görüldüğ̈̈ üzere, bu yöntemde tüm batarya hücreleri dolmaya başlamıştır. Üst sınır değer olan 4.2 V'ye ulaşan Bat17 hücresi dengelemeye girmiş ve bu hücrenin daha fazla dolumu engellenmiştir. Diğer hücreler ise belirlenen üst sinır (4.2V)'a erişinceye kadar şarj olmaya devam etmektedir. Ayrıca bu ölçümlerdeki değerler Matlab'da "fillter" komutu kullanılarak gürültünün azaltılmasıyla batarya hücrelerinin gerilim grafikleri Şekil 10'daki gibi daha belirgin olarak gösterilebilir. 
European Journal of Science and Technology

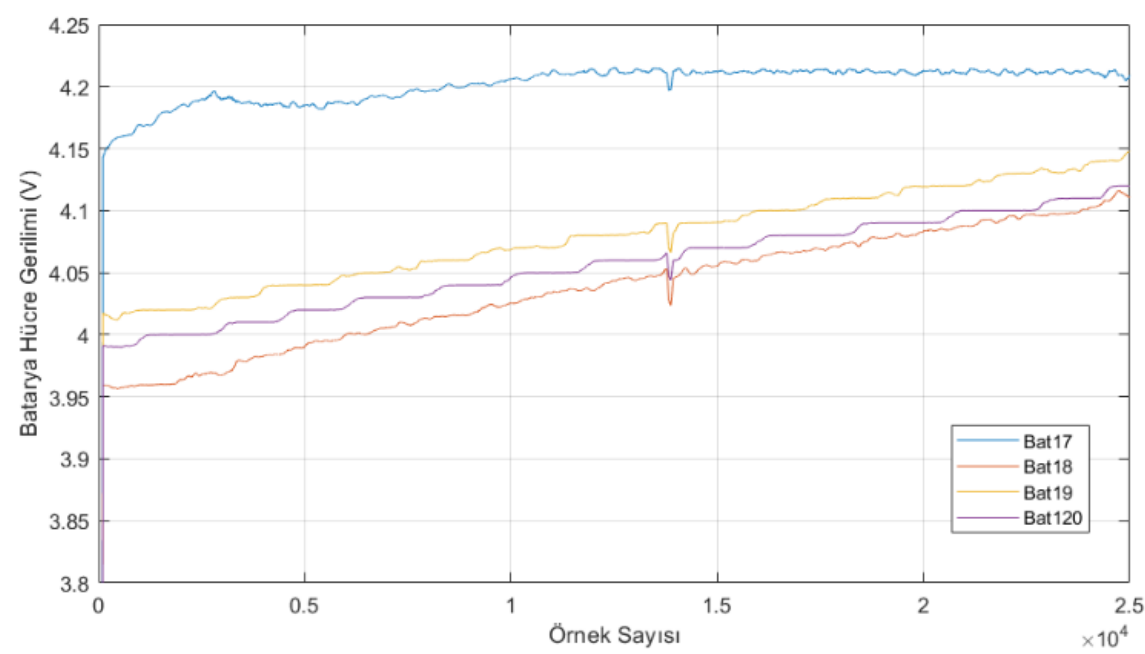

Şekil 10. Üst sinır değer dengeleme hücre gerilimleri (filtreli)

BYS pasif hücre dengelemesi algoritmasında ikinci yöntem olarak, "batarya hücre gerilimlerinin fark değerleri"ne göre yapılan dengelemede elde edilen batarya hücre gerilimlerinin grafiği Şekil 11'de gösterilmektedir.

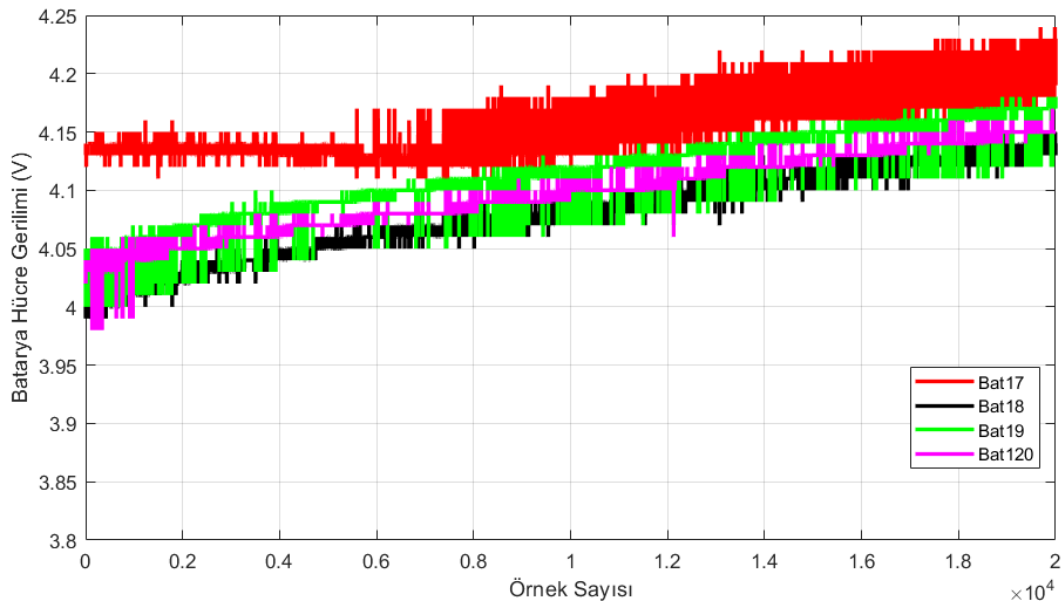

Şekil 10. Fark dengeleme hücre gerilimleri

Bu yöntemde ölçümler alınırken fark $0.05 \mathrm{~V}$ olarak ayarlanmıştır. Burada Bat18 gerilimi en düşük batarya hücresidir. Şekil 11'da görüldüğ̈̈ gibi, sadece Bat17 hücresinin gerilim değeri ile Bat18 batarya hücresinin gerilim fark1 0.05 V'den büyüktür. Bundan dolayı Bat17 hücresi dengelemeye girmiş ve hücrenin dolması engellenmiştir. Diğer batarya hücreleri dolmaya başlamış ve en düşük gerilimli hücre ile Bat17'nin arasındaki gerilim farkı 0.05 V'nin altına düştüğü anda Bat17 hücresi dengelemeden çıkmış ve hücre dolmaya başlamışıır. Aradaki bu fark korunarak tüm batarya hücreleri beraber dolmaya devam etmiştir. Ayrıca bu dengeleme yönteminde elde edilen ölçümler Matlab'da "fillter" komutu ile gürültünün azaltılması için elde edilen batarya hücrelerinin gerilim grafikleri Şekil 12'de verilmiştir.

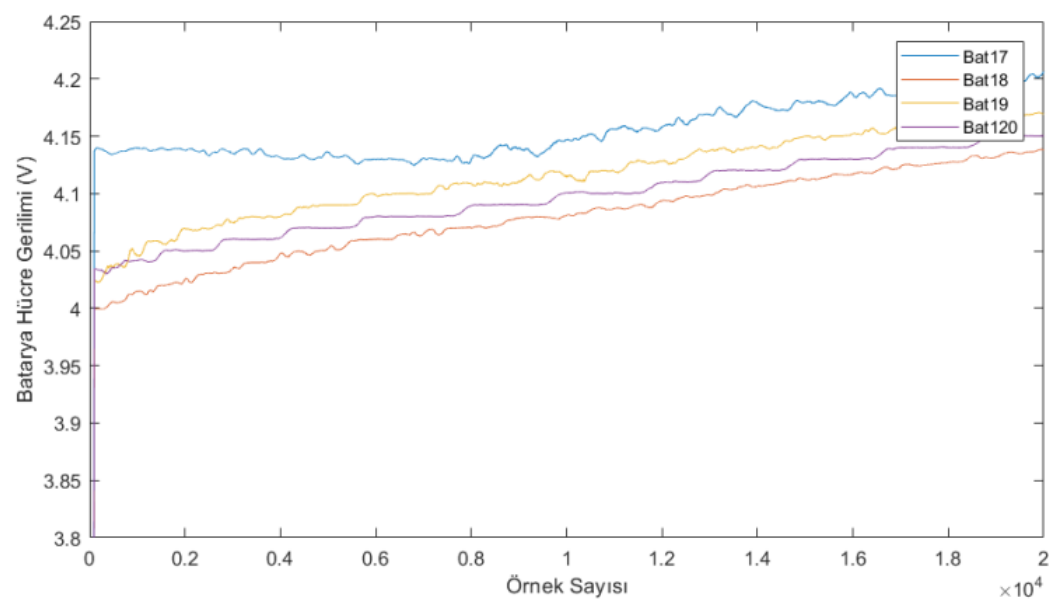

Şekil 12. Fark dengeleme hücre gerilimleri (filtreli) 


\section{Sonuç}

Bu çalışmada EA'larda enerji kaynağı olarak kullanılan bataryalar için düşük maliyetli BYS tasarlanmış ve gerçekleştirilmiştir. BYS kartı 20 adet seri batarya hücresini kontrol edebilmektedir. Bu kartın tasarımında merkezi BYS sistemi tercih edilmiş ve SMD devre elemanları kullanılarak kartın sade olması sağlanmış, boyutu küçültülmüş ve maliyeti düşürülmüştür. Prototip olarak yapılan BYS kartında batarya hücreleri için yüksek gerilim, düşük gerilim ve sıcaklık korumaları mevcuttur. Ayrıca batarya hücrelerinde azami verim alınabilmesi amacıyla hücrelerin dolumu esnasında pasif dengeleme sistemi uygulanmaktadır. BYS ile batarya hücrelerinin her birinin SoC'ları hesaplanmış ve SoH kestirimleri yapılmıştır. Gerçekleştirilen merkezi BYS yapısındaki kartın tasarımında yukarıdaki özellikleri test edilmiş ve BYS'nin etkin bir şekilde çalıştı̆̆ gözlemlenmiştir.

BYS tasarımında pasif dengeleme sistemlerinin verimsiz olduğu belirtilse de, tasarım ve maliyet açısından büyük kolaylık sağladığ1 aşikardır. Aktif ve pasif dengeleme yöntemlerinin karşılaştırması yapılırken, tüm etkenler (maliyet, boyut, kurulum kolaylı̆̆ı, hız) değerlendirildiği zaman, tasarlanan ve gerçeleştirilen BYS'nin mevcut uygulamalar için kullanılabilir olduğu görülmektedir.

\section{Kaynakça}

[1] Situ L. Electric vehicle development: the past, present \& future. In: Proceedings of the 3rd international conference on power electronics systems and applications, Hong Kong, China, 20-22 May 2009. New York: IEEE.

[2] Frost DF and Howey DA. Completely decentralized active balancing battery management system. IEEE T Power Electr 2018; 33(1): 729-738.

[3] Cao, J., Schofield, N., Emadi, A., 2008. Battery balancing methods: A comprehensive review, IEEE Vehicle Power and Propulsion Conference, Harbin, China, 1-6.

[4] Texas instrument, "Intelligent battery management and charging for electric vehicles," from www.ti.com.

[5] Farmann, A. and Sauer, D. U., 2016. A comprehensive review of on-board State-of-Available-Power prediction techniques for lithium-ion batteries in electric vehicles. Journal of Power Sources. 329, 123-137.

[6] Saw, L.H., Ye, Y. and Tay, A.A.O., 2014. Electro-thermal analysis and integration issues of lithium ion battery for electric vehicles. Applied Energy. 131, 97-107.

[7] Andrea, D. 2010. Battery management systems for large lithium ion battery packs. Artech house, Norwood, Massachusetts, USA.

[8] Watrin, N., Blunier, B. and Miraoui, A. (2012a). Review of adaptive systems for lithium batteries state-of-charge and state-ofhealth estimation. 2012 IEEE Transportation Electrification Conference and Expo (ITEC), IEEE, 1-6.

[9] Prajapati, V., Hess, H., William, E. J., Gupta, V., Huff, M., Manic, M., Rufus, F., Thakker, A. and Govar, J. (2011). A literature review of state of-charge estimation techniques applicable to lithium poly-carbon monoflouride (LI/CFx) battery. India International Conference on Power Electronics 2010 (IICPE2010), IEEE, 1-8.

[10] Chiasson, J. and Vairamohan, B. (2003). Estimating the state of charge of a battery. Proceedings of the 2003 American Control Conference, 2003, IEEE, 2863-2868.

[11] Ng, K.-S., Moo, C.-S., Chen, Y.-P. and Hsieh, Y.-C. (2008). State-of-charge estimation for lead-acid batteries based on dynamic open-circuit voltage. 2008 IEEE 2nd International Power and Energy Conference, IEEE, 972-976.

[12] Abu-Sharkh, S. and Doerffel, D. 2004. Rapid test and non-linear model characterisation of solid-state lithium-ion batteries. Journal of Power Sources, 130:1-2, 266-274.

[13] Anbuky, A. H. and Pascoe, P. E. 2000. VRLA battery state-of-charge estimation in telecommunication power systems. IEEE Transactions on Industrial Electronics, 47:3, 565-573.

[14] Sato, S. and Kawamura, A. (2002). A new estimation method of state of charge using terminal voltage and internal resistance for lead acid battery. Proceedings of the Power Conversion Conference-Osaka 2002 (Cat. No. 02TH8579), IEEE, 565-570.

[15] Huet, F. 1998. A review of impedance measurements for determination of the stateof-charge or state-of-health of secondary batteries. Journal of Power Sources, 70:1, 59-69.

[16] Bundy, K., Karlsson, M., Lindbergh, G. and Lundqvist, A. 1998. An electrochemical impedance spectroscopy method for prediction of the state of charge of a nickel-metal hydride battery at open circuit and during discharge. Journal of Power Sources, 72:2, 118125.

[17] Ran, L., Junfeng, W., Haiying, W. and Gechen, L. (2010). Prediction of state of charge of lithium-ion rechargeable battery with electrochemical impedance spectroscopy theory. 2010 5th IEEE Conference on Industrial Electronics and Applications, IEEE, 684688.

[18] Ng, K.-S., Huang, Y.-F., Moo, C.-S. and Hsieh, Y.-C. (2009). An enhanced coulomb counting method for estimating state-of-charge and state-of-health of lead-acid batteries. INTELEC 2009-31st International Telecommunications Energy Conference, IEEE, 1-5.

[19] Kim, J. and Cho, B.-H. 2011. State-of-charge estimation and state-of-health prediction of a Li-ion degraded battery based on an EKF combined with a per-unit system. IEEE transactions on Vehicular Technology, 60:9, 4249-4260.

[20] Pop, V., Bergveld, H., Notten, P., het Veld, J. O. and Regtien, P. P. 2009. Accuracy analysis of the State-of-Charge and remaining run-time determination for lithium-ion batteries. Measurement, 42:8, 1131-1138.

[21] Wang, J., Cao, B., Chen, Q. and Wang, F. 2007. Combined state of charge estimator for electric vehicle battery pack. Control Engineering Practice, 15:12, 1569-1576. 